\title{
THE RELATIONSHIP BETWEEN IMMIGRATION, ACCULTURATION AND PSYCHOLOGICAL WELL-BEING THE CASE OF TURKISH YOUTH IN AUSTRIA ${ }^{1}$
}

\author{
Levent KIYLIOĞLU ${ }^{2}$, Heinz WIMMER ${ }^{3}$
}

\begin{abstract}
Psychological research in culturally plural societies has traditionally been divided into two domains: acculturation and ethnic relations. Berry's model of acculturation and psychological well-being is highly regarded and widely recognized as in the field. His twodimensional model of acculturation is based upon the multicultural ideology where individuals and groups are given the opportunity to choose among various elements of ethnic and host cultures to form their own unique blends of identity and culture. The findings support the Berry's proposal that acculturation is two-dimensional (ethnic/cultural and host society identification) for acculturating immigrants. But the process of acculturation is different depending on the life domains being considered. Youngsters do not endorse both cultures to the same degree in all domains, which means acculturation preferences for Turkish youngsters between the ages of 12-15 are domain dependent. In terms of average point acculturation preferences, Turkish youth endorsed integration more than any other acculturation strategies. Significant correlation was found among self-esteem and separation acculturation attitude for reading books domain. Second significant correlation was found among self-esteem and marginalization acculturation attitude for work domain.
\end{abstract}

Keywords: Immigration, acculturation, Turkish youth in Austria

Kiylığlu, L. and Wimmer, H. (2015). The Relationship between Immigration, Acculturation and Psychological Well-being The Case of Turkish Youth in Austria. Nesne, 3 (5), s.1-19.

\footnotetext{
${ }^{1}$ This article is based on a Master's Thesis conducted by the first author under the supervision of the second

${ }^{2}$ Ph.D. Candidate, Ankara University, Institute for Social Sciences, levent.kiylioglu@ gmail.com

${ }^{3}$ Prof. Dr., Salzburg University, Department of Psychology, heinz.wimmer@ sbg.ac.at
} 


\title{
GÖÇ, KÜLTÜRLEŞME VE PSIKOLOJIK İYİ OLUŞ ARASINDAKİ İLIŞKİ: AVUSTURYA'DAKİ TÜRK GENÇLERININ DURUMU
}

\begin{abstract}
ÖZET
Çok kültürlü toplumlarda geleneksel olarak psikoloji çalışmaları iki bölüme ayrılmıştır: kültürleşme ve etnik ilişkiler. Berry’nin kültürleşme ve psikolojik iyi oluş modeli, alanda saygınlığı olan ve yaygın olarak kabul edilen bir modeldir. İki boyutlu kültürleşme modeli, bireylerin ve grupların özgün kimlik ve kültür karışımlarını oluşturmak için ev sahibi ve etnik kültürün çeşitli unsurları arasından seçim yapma fırsatının verilmesine dayanmaktadır. Bulgular göçmenlerde kültürleşmenin iki boyutlu (etnik ve ev sahibi kimliği) olduğunu belirten Berry'nin iddialarını desteklemektedir. Ancak, göz önüne alınan yaşam alanlarına bağlı olarak kültürleşme süreci farklılık gösterir. Gençler her bir yaşam alanında iki kültürü de aynı derecede onaylamamaktadır. 12-15 yaşlarındaki Türk geçlerinin kültürleşme tercihleri yaşam alanına bağlı olarak değişiklik göstermektedir. Ortalama kültürleşme puanları açısından Türk gençleri, entegrasyonu diğer kültürleşme stratejilerine tercih etmiştir. Benlik saygısı ile kitap okuma alanı için ayrılan kültürleşme tutumu arasında anlamlı ilişki bulunmuştur. İkinci anlamlı ilişki ise benlik saygısı ile çalışma alanı için marjinalleşen kültürleşme tutumu arasında tespit edilmiştir.
\end{abstract}

Anahtar Kelimeler: Göç, kültürleşme, Avusturya'da Türk gençleri 
As a result of immigration, many societies become culturally plural. That is, people of many cultural backgrounds come to live together in a diverse society. In many cases they form cultural groups that are not equal in power (numerical, economic, or political). These power differences have given rise to popular and social science terms such as "mainstream", "minority", "ethnic groups" etc (Berry, 1997).

Psychological research in culturally plural societies has traditionally been divided into two domains: acculturation and ethnic relations. The first has came us from anthropology, and considers the issue of how groups and individuals may change as a result of continuous intercultural contact. The most recent, and arguably most influential, account of the post-migration process argues that acculturation (i.e. the changes to individuals and groups as a result of being in contact with members of another culture) is the major challenge confronting immigrants. There are two main perspectives among the theories of acculturation. One emphasizes a linear process of assimilation, and the other emphasizes cultural plurality. In the first perspective, the term acculturation is often equated with assimilation, and it more commonly refers to the process of acquiring the host society's values and behaviours. The assimilationist model points a unidirectional change toward the mainstream society and implies an eventual disappearance of the original ethnic/cultural identity. In contrast, the second model emphasizes cultural pluralism. It is two-dimensional (host and ethnic/cultural identification) in the sense that it recognizes that ethnic groups and their members preserve, in varying degrees their heritage cultures while adapting to the mainstream society (Berry, 1997).

Maintenance of heritage culture among groups)

Cultural adaptation (relationship sought

Figure 1. The one-dimensional acculturation model

Conception of acculturation as assimilation has informed much of research on culture change, but they fail to account for numerous individual differences and other factors affecting the rate of adaptation to the new culture, such as premigration exposure to the mainstream culture, residence in an ethnic neighbourhood, willingness to seek language education, and frequency of contact with individuals from the mainstream culture (Ryder, Alden \& Paulhus, 2000). Arends-Toth (2002) pointed out that this method cannot distinguish a bicultural individual who strongly 
identifies with both groups, from a marginalized individual, who does not identify with either group.

Two-dimensional models of acculturation, based largely on the work of Berry, recognize that the two dominant aspects of acculturation, namely, preservation of one's heritage culture and adaptation to the host society, are conceptually distinct and can vary independently (Liebkind, 2001). Ryder et. al. (2000) pointed out that the two-dimensional model is based on two core assumptions. First, the model presupposes that individuals differ in the extent to which self-identity includes culturally based values, attitudes, and behaviours. Culture may play a large role in the identities of some individuals, whereas others may base their identity more on factors such as occupation or religion. Second, individuals are capable of having multiple cultural identities, each of which may independently vary in strength.

\section{Cultural Adaptation (relationship sought among groups)}

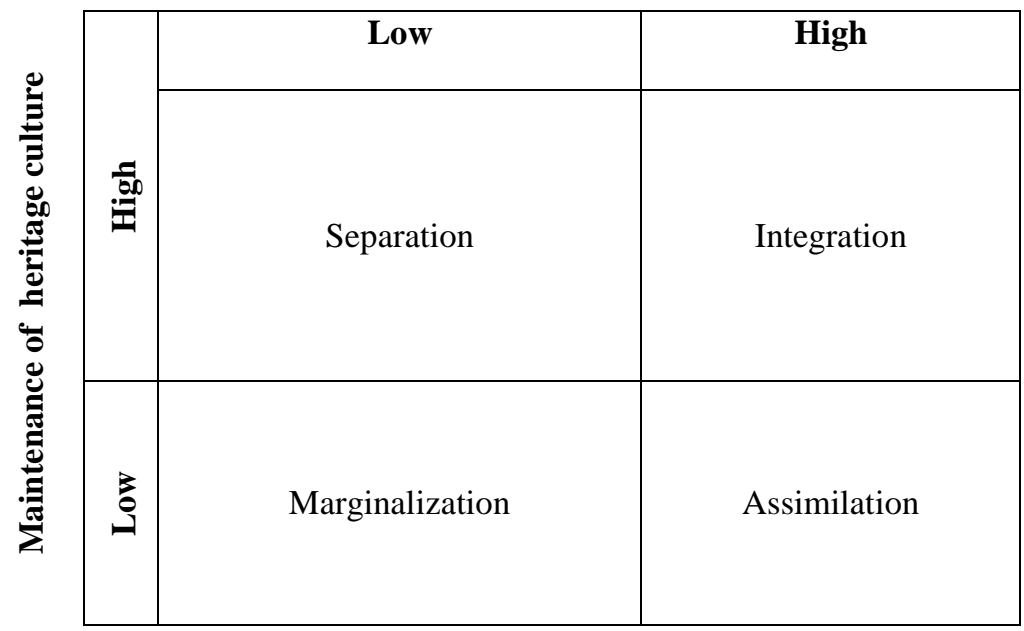

Figure 2. The two-dimensional acculturation model of Berry 
Berry (2001) assumed that within cross-cultural psychology, there is at the conceptual level a clear tendency to move toward a two-dimensional model of acculturation. According to this model, depending on whether the individual chooses to (a) maintain or (b) reject his or her own cultural/ethnic identity, and (c) maintain or (d) reject relationships with larger society (host culture), the individual adopts an acculturation attitude of integration (a-c), assimilation (b-c), separation/ segregation (a-d), or marginalization (b-d) (Nesdale, 2002). The integration strategy reflects a desire to maintain key features of the immigrant's culture while there is a simultaneous interest in adopting elements of the majority culture. Assimilation refers to the loss of original culture and complete absorption in the majority culture. The separation strategy reflects a desire to maintain the minority culture while rejecting the majority culture. Finally, marginalization amounts to the rejection of both cultures.

The stress and coping tradition has been a very popular approach to the study of acculturation (Berry, 1997; Ward \& Rana-Deuba, 1999). Within this framework, both one-dimensional and two-dimensional models of acculturation have been applied. Both kinds of models conceptualize the acculturation process as potentially stressful because of language problems, perceived discrimination, perceived cultural incompatibilities, identity conflicts, shortage of social support, and the like. Lazarus (1997) noted that generational conflicts are a source of stress in immigrant families as the children beginning to acculturate to the new society more rapidly and perhaps more fully than their parents.

Phinney (1990) pointed out that, particularly during adolescence, it is possible that conflicts between demands of parents and peers are maximal, or that the problems of life transitions between childhood and adulthood are compounded by cultural transitions. Developmental issues of identity come to fore at this time and interact with questions of ethnic identity, multiplying the questions about who one really is.

Negative outcomes occur when stressors of this kind exceed the individual's coping resources, or protecting mediators. In contrast to the stress and coping perspectives, social learning approaches emphasize the role of learning in the acquisition of culturally appropriate skills. Berry and Sam (Berry, 1997; Sam, 2000) identified depression, anxiety, and psychosomatic problems as the most common mental health consequences among acculturating individuals. Verkuyten and Thijs (2002) noted that positive attitude towards both groups (cultures) is an important feature of bicultural competence that can reduce feelings of cultural conflict and adjustment-related stress. 
Successful acculturation has been defined by Berry (2000) in terms of adaptation which is an outcome where individuals can manage their new lives very well. Berry indicated that supportive relationship with both cultures (i.e. having twosocial support system) is most predictive of successful adaptation. Successful acculturation has been defined by Liebkind (2001) in terms of mental and physical health, psychological satisfaction, high self-esteem, competent work performance, and good grades in school. According to Nesdale (2002), marginalization is associated with higher acculturative stress than are other acculturation attitudes, and that assimilation is related to life satisfaction, while integration is related to feelings of competence.

Acculturation may be "uneven" across different domains of behaviour and social life: For example, one may seek economic assimilation (in work), linguistic integration (by way of bilingualism), and marital separation (by endogamy). Klinger and Bierbrauer (2001) pointed out that not all spheres of life are likely to be influenced to the same degree. For example, about one third of immigrant Turks in Germany prefer to live in neighbourhoods with both Germans and immigrants of similar cultural heritage. In contrast, they prefer a separation-type mode with respect to the use of news media and religious customs. Arends-Toth (2002) studied Turkish immigrants in Netherlands and found that the two-dimensional acculturation model for Turks was preferred only in public domains.

Berry (2000) noted that integration strategy can be pursued only in societies that are explicitly multicultural, in which certain psychological preconditions are established. These preconditions are the widespread acceptance of the value to a society of cultural diversity (i.e. the presence of a multicultural ideology), and of low levels of prejudice and discrimination; positive mutual attitudes among ethno cultural groups (i.e. no specific intergroup hatreds); and a sense of attachment to, or identification with, the larger society by all individuals and groups. Arends-toth (2002) found that conceptually, acculturation is a more homogeneous construct for majority people while it is more heterogeneous for minorities. The structure of acculturation (combination of cultural maintenance and adaptation to the host society) is different in two groups: acculturation is one-dimensional in majority group members and two-dimensional in minority groups. For majority group members, cultural maintenance and adaptation to the host society are conflicting options: maintenance of minority culture implies a lack of adaptation to the majority culture, and vice versa.

The current research explored the relationship between the acculturation attitudes (strategies) and psychological well-being of the Turkish youth to Austria. I hypothesized and expected to find out that integration, that is, simultaneous ethnic 
retention and adaptation to the new society, to be most adaptive mode of acculturation and the most conducive to youngsters' psychological well-being, whereas marginalization is the worst.

The size of the Turkish immigrant population has been increasing steadily and this presents a need to understand how they live through the process of acculturation and adapt to life in Austria. The following part of the article explained the method of the study.

\section{Method}

This part of the study includes participants, materials, and procedure.

\section{Participants}

A total of 100 Turkish youngsters who were recruited through schools in Province Salzburg participated in the present study. In this study, Turkish youngsters refer to persons who were born in Turkey or who had at least one parent who was born in Turkey. A total population of Turkish people living in Province Salzburg was around 11.000 in 2004. Data were collected in 2004 in Province Salzburg of Austria.

The sample consisted of 50 females and 50 males; ranging from 12 to 15 years. Their mean age was $13.79(\mathrm{SD}=1,01)$. This age group was chosen because most acculturation attitudes are formed in this life period.

67 participants was born and always lived in Austria. 25 participants were born in Turkey and have been living more than 5 years in Austria. The other 8 participants lived less than 5 years in the host country.

All of the participants were in lower school tracks (Hauptschule-middle school) within the Austrian educational system. This sample was quite similar to the Turkish youth population in Austria at large, regarding gender, age, and level of education. Most of the Turkish parents either have no formal education or have only primary education. 


\section{Materials}

The questionnaire included sections on: demographic/ background information, acculturation attitudes, and adaptation (psychological well-being) measures. The selection of the specific predictor variables was based on the strong relations in the literature between the predictor and the particular facet of adaptation.

Demographic/ background information: The demographic variables were: age, sex, length of residence in Austria, which school the youngsters attend to.

Acculturation attitudes: Five attitude domains that are important in the lives of the Turkish youngsters were specified: work, friendship, language use, books, interest in nation. Based on Berry's (1997) acculturation model, four items for each domain were generated, one for each acculturation attitude. The scale for measuring acculturation attitudes were adopted from the studies of Van de Vijver, HelmsLorenz and Feltner (1999) who originally developed 10 life domains. Items dealing with the integration strategy expressed a positive attitude toward both cultures (e.g., I prefer to have Turkish and Austrian friends), (alpha=.15) ; separation items had a positive evaluation of Turkish culture and a negative evaluation of Austrian culture (e.g., I prefer to have Turkish friends than Austrian),(alpha=.51); assimilation strategy referred to a negative evaluation of the Turkish culture and a positive evaluation of the Austrian culture (e.g., I prefer to have Austrian friends than Turkish),(alpha=.60); in items referring to marginalization both cultures were negatively evaluated (e.g., I do not want to have Austrian and Turkish friends),(alpha=.17). Because Cronbach's alpha for integration and marginalization were very low, these attitude scales should not be used. Nevertheless, in addition to assimilation and separation, I also used integration and marginalization as an attitude scale. Because John Berry (1997) proposed that one-dimensional structure (see Figure 1) is to be expected from respondents of the general public or majority in a country, whereas with respondents from specific ethno cultural communities fourfactor structure (see Figure 2) is more likely to be found. Four items for each attitude domain were randomly ordered in each domain. In order to maximize simplicity and avoid unwanted cognitive and linguistic aspects in the questionnaire, a dichotomous answer was asked instead of the Likert scales, ranging from agree to disagree.

It was found that Cronbach's alpha for integration (alpha=.15) and marginalization (alpha=.17) were very low. These attitude scales are not consistent and should not be used. Possible explanation for this low consistency is that acculturation preferences of the Turkish youth are changing from domain to domain 
which means it is domain specific. Youngsters do not endorse both cultures to the same degree in all domains, choosing selective aspects instead.

Psychological well-being (adaptation): Two scales measuring self-esteem and coping with problems were asked to create a composite psychological adaptation score.

Self-esteem: The 10-item self-esteem scale is a subscale of "The Frankfurt Selfconcept Scale" (FSKN; Deusinger, 1986). It was used to measure how the individual feels about the self in a comprehensive manner (e.g., I am nobody). In line with perspective of the World Health Organization on health as a "state of complete physical, mental and social well-being, and not merely the absence of disease and infirmity", it is normal to focus on positive aspects of health as well. The items were rated on a 6-point Likert scale ranging from 1 (totally disagree) to 6 (totally agree), with higher scores indicating higher self-esteem (alpha=.19). Self- esteem scale is a publicized scale that means it should be consistent. In order to see if it is really consistent, I recalculated the Cronbach's alpha and found out that alpha is very low which means it is not consistent. This scale should not be used.

Coping with problems: The 10-item coping with problems scale is a subscale of "The Frankfurt Self-concept scale" (FSKN; Deusinger, 1986).It was used to measure how the individual assess his or her ability of coping with problems and difficulties in everyday life (e.g., I hust get along well like others). The items were rated on a 6point Likert scale ranging from 1 (totally disagree) to 6 (totally agree), with higher scores indicating higher self-assessment of coping ability (alpha=.47).

\section{Procedure}

The questionnaire in this study consisted of 43 items. All measures were originally in German; all measures were translated into Turkish using the method of forward and backward translation.

Participants were recruited through schools individually. Where possible, the questionnaire was also administered to groups of students at the schools. Respondents filled in the questionnaire at their schools (Hauptschulen).94\% of the participants used the German version of the questionnaire, $6 \%$ of the Turkish version. 


\section{Results}

In order to answer two research questions, it was carried out descriptive and correlation analysis using SPSS version 11.

\section{Summary scores of acculturation attitudes and psychological well-being}

As we see from the Table 1, integration is the highest acculturation score. Our participants, namely second generation Turkish youth in Province Salzburg preferred integration acculturation attitude more than any other acculturation preferences. Assimilation acculturation attitude is the second valued acculturation strategy. Marginalization is the least preferred strategy. Youngsters' self-esteem score is slightly higher than coping with problems. But from these scores we cannot say either their psychological well-being is good or not. Because this is a publicized scale, we have to compare summary scores of the psychological well-being measures with the test norms in order to find their exact place.

Table 1. Summary scores of acculturation attitudes and psychological well-being

\begin{tabular}{lccc}
\hline Variable & Mean & SD & Possible range of scores \\
\hline $\begin{array}{l}\text { Acculturation } \\
\text { Attitudes }\end{array}$ & 3,52 & 0,87 & $0-5$ \\
$\begin{array}{l}\text { Integration } \\
\text { Separation }\end{array}$ & 1,27 & 1,22 & $0-5$ \\
$\begin{array}{l}\text { Assimilation } \\
\text { Marginalization }\end{array}$ & 2,00 & 1,23 & $0-5$ \\
$\begin{array}{l}\text { Psychological Well- } \\
\text { being }\end{array}$ & 0,47 & 0,65 & $0-5$ \\
Self-esteem & 44,8 & 8,9 & $10-60$ \\
Coping with prob. & 41,5 & 7,5 & $10-60$ \\
\hline
\end{tabular}

\section{Specific analyses of attitudes on 5 different domains}

In Table 2, it was analyzed the acculturation attitudes of all kids, boys, and girls on 5 different attitude domains. It was also calculated average attitudes for each given groups.

Table 2 shows that Turkish youth prefer the integration acculturation strategy over the other three options (assimilation, separation, and marginalization) 
on the friendship, language use, and interest in nation domains. That means they are interested in two given languages, two nations, and friends from both cultural backgrounds. Integration is the least preferred strategy on work domain. On reading books domain, although integration is the most valued strategy, there is not a big difference between integration, assimilation, and marginalization preferences.

Table 2. Specific analyses of attitudes on 5 different domains

\begin{tabular}{lcccccc}
\hline & Work & Friendship & $\begin{array}{c}\text { Language } \\
\text { use }\end{array}$ & $\begin{array}{c}\text { Books } \\
\text { Interest in } \\
\text { nation }\end{array}$ & Average \\
\hline BOYS & 22 & 90 & 92 & 42 & 82 & 65,5 \\
Integraion & 12 & 64 & 16 & 6 & 48 & 29,2 \\
Separation & 80 & 12 & 34 & 36 & 22 & 36,8 \\
Assimilation & 6 & 0 & 8 & 34 & 2 & 10 \\
Marginalization & & & & & & \\
GIRLS & 26 & 98 & 96 & 64 & 92 & 75,2 \\
Integraion & 8 & 46 & 10 & 12 & 32 & 21,6 \\
Separation & 12 & 58 & 46 & 16 & 43,2 \\
Assimilation & 84 & 0 & 0 & 26 & 6 & 8,8 \\
Marginalization & 12 & & & & & \\
ALL KIDS & & 94 & 94 & 53 & 87 & 70,4 \\
Integraion & 10 & 55 & 13 & 9 & 40 & 25,4 \\
Separation & 82 & 12 & 46 & 41 & 19 & 40 \\
Assimilation & 9 & 0 & 4 & 30 & 4 & 9,4 \\
Marginalization & 9 & & & & & \\
\hline
\end{tabular}

Second favoured strategy for friendship and interest in nation domain is separation; but for the language use domain, assimilation is the second preferred strategy. Although both countries and friends from two given cultural background are important for them, they want to know more about Turkey than Austria, and prefer to have Turkish friends than Austrian. On the contrary, using German language is more important for them than Turkish.

On work domain, assimilation is the most valued strategy. Most of them were born and lived only in Austria, and as a result want to stay and work in this country. But this domain is not related to cultural preference (economic assimilation).

Marginalization option is highly valued on reading books domain. Some of them simply do not want to read books in any given languages. But this should not 
mean that they are marginalized. Probably they enjoy spending their time with any other activities such as watching TV, playing games etc.

These results demonstrate domain dependence of acculturation orientations of our participants; youngsters do not endorse both cultures to the same degree in all domains, choosing selective aspects instead.

When we compare the boys with the girls, we can see little differences between given groups. Boys' separation is stronger and assimilation is weaker. Turkish culture was stronger valued by boys than girls. Opposite is true for girls. Girls were more assimilated than boys.

It was compared the acculturation attitudes of participants who were born in Turkey $(\mathrm{N}=33)$ on each attitude domains with kids who are living in Austria since birth $(\mathrm{N}=67)$, but could not find any significant differences between given groups.

\section{Psychological well-being for different age groups and gender}

Table 3 shows mean, standard deviation, and percentage value of our participant's psychological well-being outcomes for different age groups and gender.

In order to see their exact position, I compared the participants' test scores from self-esteem and coping with problems with the "Frankfurt Self-concept Scale" (FSKN) norms for appropriate age groups. For each test score of the FSKN, there is also percentage value that a person or group of people can compare his or her position with the norm sample.

We can see from the Table 3 that Turkish youngsters' psychological wellbeing from both scales (self-esteem and coping with problems) is slightly under average level of 50 percent for both gender and age group. Youngsters' self-esteem is higher than coping with problems at all groups except for older boys.

When we compare two genders with each other, we can see that boys' psychological well-being is better than girls. Older girls have the worst psychological well-being.

When we compare the groups depending on age, we can find out that youngsters' (boys + girls) self-esteem is decreasing but coping with problems is increasing. Girls' psychological well-being from both scales is decreasing slightly. Boys' coping with problems is increasing greatly. 
Table 3. Psychological well-being for different age groups and gender

\begin{tabular}{|c|c|c|c|c|}
\hline & \multicolumn{2}{|c|}{ Self-esteem } & \multicolumn{2}{|c|}{ Coping with Problems } \\
\hline & $\mathrm{M}$ & $\mathrm{SD}$ & $\mathrm{M}$ & $\mathrm{SD}$ \\
\hline GROUPS & PR & & PR & \\
\hline \multicolumn{5}{|l|}{ BOYS } \\
\hline Younger (12-13 years old) & 45,8 & 9,5 & 40,5 & 8 \\
\hline $\mathrm{N}=16$ & 42 & & 26 & \\
\hline Older (14-15 years old) & 45,3 & 7,7 & 43,8 & 7,5 \\
\hline $\mathrm{N}=34$ & 39 & & 46 & \\
\hline Combined (all boys) & 45,5 & 8,2 & 42,7 & 7,7 \\
\hline $\mathrm{N}=50$ & 40 & & 39 & \\
\hline \multicolumn{5}{|l|}{ GIRLS } \\
\hline Younger (12-13 years old) & 45,4 & 7,6 & 41,3 & 6,3 \\
\hline $\mathrm{N}=22$ & 40 & & 31 & \\
\hline Older ( $14-15$ years old) & 43,1 & 10,7 & 39,5 & 7,8 \\
\hline $\mathrm{N}=28$ & 30 & & 21 & \\
\hline Combined (all girls) & 44,1 & 9,5 & 40,3 & 7,2 \\
\hline $\mathrm{N}=50$ & 50 & & 26 & \\
\hline YOUNGER (boys+girls) & 45,5 & 8,3 & 41 & 6,9 \\
\hline $\begin{array}{c}12-13 \text { years old } \\
\mathrm{N}=38\end{array}$ & 40 & & 29 & \\
\hline OLDER (boys+girls) & 44,3 & 9,2 & 41,9 & 7,9 \\
\hline $\begin{array}{c}14-15 \text { years old } \\
\mathrm{N}=62\end{array}$ & 35 & & 34 & \\
\hline COMBINED (all kids) & 44,8 & 8,9 & 41,5 & 7,5 \\
\hline $\mathrm{N}=100$ & 37 & & 32 & \\
\hline
\end{tabular}

\section{Correlations between acculturation attitudes and psychological well-being}

Pearson correlations were carried out among all kids' generalized (average point) acculturation preferences which were integration, assimilation, separation, and marginalization and two scales of psychological well-being measures (selfesteem and coping with problems). As we see from Table 4, there was not found any significant correlation among given variables. This result is not consistent with Berry's proposal, and my own hypothesis was not proved to be correct.

Later on, separate Pearson correlations were carried out between each attitude domains (work, friendship, language use, reading books, interest in nation) and two scales of psychological well-being measures. First, significant but low 
Kıylıoğlu, L. and Wimmer, H. (2015). The Relationship between Immigration, Acculturation and Psychological Well-being The Case of Turkish Youth in Austria. Nesne, 3 (5), s.1-19.

correlation was found among self-esteem and separation acculturation attitude for reading books

Table 4. Correlations between average point acculturation attitudes and psychological wellbeing

\begin{tabular}{lcc}
\hline Variables & 1 & 2 \\
\hline 1. Self-esteem & - & - \\
2. Coping with problem & - & - \\
3. Integration & -.10 & -.17 \\
4. Assimilation & -.06 & -.08 \\
5. Separation & .17 & .05 \\
6. Marginalization & -.13 & .10 \\
\hline
\end{tabular}

domain. These two given variables were positively correlated $(r=.278, p<.01)$. It means that youngsters who prefer to read books in Turkish than in German language have significantly higher self-esteem. They feel better about themselves in a comprehensive manner and have a positive self-image. Second significant, also low correlation was found among self-esteem and marginalization acculturation attitude for work domain. These two given variables were negatively correlated $(r=-.254, p<$ .05). It means that youngsters who do not want to work later on their life neither in Austria nor in Turkey evaluate themselves negatively and have significantly lower self-esteem.

\section{Discussion}

These results indicate that the second generation Turkish youth to Austria endorsed integration which means that they attached to the Turkish and Austrian culture. They want to maintain Turkish culture and at the same time adapt to the Austrian society. This finding is consistent with the Berry's (1997) acculturation model that acculturation is two dimensional (ethnic/cultural and host society identification) for acculturating immigrants. But the process of acculturation is different depending on the life domains being considered.

These results demonstrate domain dependence of acculturation orientations of the Turkish youth; youngsters do not endorse both cultures to the same degree in all domains, choosing selective aspects instead. Integration is often based upon the assumption of an equal preference of cultural maintenance and adaptation to the host society. Integration for Turkish youngsters is not equal preference of two cultures as the integration strategy assumes, but rather the specific combination of cultures in 
which different domains are combined in different ways. As Arends-Toth (2002) pointed out, domain specific model is based on the assumption that an individual's preference for adaptation to the new culture or ethnic/cultural retention varies across domains and situations. On language use and reading books domain, Austrian culture was more favoured than the Turkish culture. It may be due to participants' age. At this age, they are preoccupied with studying, and as Phinney, Horenczyk, Liebkind and Vedder (2001) noted, schools are more assimilationist than other institutions and social context. They have to adapt to the requirements of school in order to acquire a position in the Austrian society later on their life. Only a few of them want to turn back to Turkey later on their life. This may be because their parents mostly came from rural or low-income urban backgrounds and their immigration motivation were mainly economic factors. Ethnic/cultural maintenance (separated identity) is very salient on friendship domain. Although they want to communicate with both Turkish and Austrian youngsters, they prefer to interact with Turkish friends. It may be because they feel themselves more secure and relaxed when they talk and play with friends from the same backgrounds. In summary, Turkish youngsters valued the Austrian culture more in utilitarian domains like language use and reading books which are related to education and society, and the Turkish culture more in the personal domains like friendship and interest in nation. These results are consistent with the Arends-Toth's (2002) findings in the Netherlands that acculturation orientations of the Turkish people are two dimensional and domain specific.

Youngster's psychological well-being stands slightly under average level. In line with the perspective of the World Health Organization (WHO) on health as a "state of complete physical, mental and social well-being, and not merely the absence of disease and infirmity", it was focused on the positive aspects of health. Girls' psychological well-being found worse than boys'. This result was frequently found in the acculturation literature in that females' psychological well-being in terms of depression is lower than males'. We need to pay attention especially to older (14-15 years old) girls' psychological well-being. They are standing at the worst level. As Verkuyten (2001) in the Netherlands concluded that Turkish girls may have to cope with more traditional gender roles. After graduating from middle school, young female from rural part of the Turkey like our participants are more likely to remain at home and maintain traditional practices. They are probably not going to follow their job and career aspirations. Future perspective such as not being effective in the new culture may reduce their psychological well-being. Turkish youngsters also suffer from absence of a vital ethnic community. A vital ethnic community provides a context in which youngsters can form a positive sense of their groups. As Liebkind (1996) pointed out, the lack of an ethnic community especially 
Kıylıoğlu, L. and Wimmer, H. (2015). The Relationship between Immigration, Acculturation and Psychological Well-being The Case of Turkish Youth in Austria. Nesne, 3 (5), s.1-19.

detrimental for the young girls, who expressed more anxiety symptoms if an ethnic community was lacking.

There was not found any significant correlations among average point acculturation preferences and any given psychological well-being measures. This result is not consistent with Berry's proposal that the acculturation strategies adopted by acculturating individuals are central factors moderating the adaptational (in this case psychological well-being) outcomes of acculturation. Only two significant but low correlations were found between each attitude domains and two scales of psychological well-being measures. One of them is among self-esteem and separation acculturation attitude for reading books domain, and the other significant correlation is among self-esteem and marginalization acculturation attitude for work domain. It was found that youngsters who prefer to read books in Turkish than in German language have significantly higher self-esteem. Ethnic/cultural maintenance (separated identity) on reading books domain is significantly and positively related to the self-esteem of the Turkish youngsters. According to Phinney et.al. (2001), both social psychological and developmental approaches support the view of a positive relationship between ethnic/cultural identity and self-esteem. Youngsters should have access to bilingual education in Austrian education system. Marginalization is detrimental for self-esteem only on work domain. It was found that youngsters who do not want to work neither in Austria nor in Turkey have significantly lower self-esteem. Austrian state should establish special institutions in order to help immigrant youngsters to decide which country they want to work and career aspirations later on their life. Probably they do not know what kind of job they want to do and their chance at the job market in two countries. Career counselling may help them.

As Jean Phinney noted (personnel communication, January 04, 2002), the measurement of acculturation is rather complicated and somewhat controversial. In spite of a large body of empirical studies, only limited conceptual and methodological advancement has been made on assessment of acculturation of migrants (Arends-Toth, 2002). The development of a standardized acculturation instrument is an essential next step in acculturation assessment. The basic problem in acculturation research is that on the one hand we do not have enough insight in the concept while on the other hand there is an urgent need for a reliable and practical acculturation measure. It is important to include items dealing with different life domains, particularly public and private domain items. Acculturation is a dynamic process that changes over time and context, making it difficult to generalize about different cultural groups or generations. Longitudinal investigations that follow immigrants over time are also needed to more fully understand what happens to individuals during the process of acculturation. The acculturation process 
requires continuous attention and monitoring. Part or the monitoring involves conducting research on the attitudes held by majority group citizens on immigration issues, because these have a major impact on policy and intercultural relations.

According to Arends-Toth (2002), in Western-European societies, integration is only partly supported by government policies and the mainstream society. In Austria, in contrast to the Netherlands, immigrants can become citizens after ten years of residence and cannot hold double citizenship, and cannot vote and be voted for in elections. People should have the right, not only in exceptional cases, to be recognized as citizens and to vote where they have been living for many years, worked, paid taxes and grown up as children.

There are a couple of limitations of my study. In order to measure acculturation attitudes, it was chosen only five attitude domains that were assumed important in the lives of the Turkish youth. As we know from the present study, acculturation attitudes are domain dependent. It was not measured personality, language proficiency, social support, cultural distance, and contact, which are also important variables in youngsters' life. Because of the non-experimental nature of the study, it is impossible to make definitive statements about the possible cause and effect relationships among the significant correlations that were found. 


\section{References}

Arends-Toth, J. (2002). Psychological Acculturation of Turkish Migrants in the Netherlands. Amsterdam: Dutch University Press.

Berry, J. W. (1997). Immigration, Acculturation, and Adaptation. Applied Psychology: An International review, 46(1), 5-68.

Berry, J. W. (2000). Socio-psychological Costs and Benefits of Multiculturalism: A view from Canada. Stockholm: Centre for Research in International Migration and Ethnic Relations.

Berry, J. W. (2001). A Psychology of Immigration. Journal of Social Issues, 57, 615-631.

Deusinger, I. M. (1986). Die Frankfurther Selbstkonzeptskalen (The Frankfurt selfconcept scale). Göttingen: Verlag für Psychologie.

Klinger, E. W., \& Bierbrauer, G. (2001). Acculturation and Conflict Regulation of Turkish Immigrants in Germany: A Social Influence Perspective. In W. Wosinska, R. B. Cialdini, D. W. Barrett, \& J. Reykowski (Eds.), The Practice of Social Influence in Multiple Groups (pp. 189-205). New Jersey: Lawrence Erlbaum Asssociates.

Lazarus, R. S. (1997). Acculturation Isn't Everything. Applied Psychology: An International Review, 46(1), 39-43.

Liebkind, K. (1996). Acculturation and Stress. Vietnamese Refugees in Finland. Journal of Cross-Cultural Psychology, 27, 161-180.

Liebkind, K. (2001). Acculturation. In R.Brown, \& S.L. Gaertner (Eds.), Blackwell Handbook of Social Psychology: Vol.3. Intergroup Processes (pp.386-404). Oxford: Blackwell.

Nesdale, D. (2002). Acculturation Attitudes and the Ethnic and Host-Country Identification of Immigrants. Journal of Applied Social Psychology, 32, 1488-1507.

Phinney, J. (1990). Ethnic identity in adolescents and adults: Review of research. Psychological Bulletin, 108, 499-514.

Phinney, J., Horenczyk, G., Liebkind, K. \& Vedder, K. (2001). Ethnic Identity, Immigration, and Well-Being: An Interactive Perspective. Journal of Social Issues, 57, 493-510.

Ryder, A.G., Alden, L.E., \& Paulhus, D.L. (2000). Is Acculturation unidimensional ob bidimensional? A head-to-head comparison in the prediction of 
personality, self-identity, and adjustment. Journal of Personality and Social Psychology, 79, 49-65. Verkuyten, M. \& Thijs, J. (2002). Multiculturalism among minority and majority adolescents in the Netherlands. International Journal of Intercultural Relations, 26, 91-108.

Ward, C. \& Rana-Deuba, A. (1999). Acculturation and Adaptation Revisited. Journal of Cross-Cultural Psychology, 30, 422-442.

Sam, D. L. (2000). Psychological Adaptation of Adolescents with Immigrant Backgrounds. The journal of Social Psychology, 140(1), 5-25.

Van de Vijver, F. J. R., Helms-Lorenz, M. \& Feltzer, M. J. A. (1999). Acculturation and Cognitive Performance of Migrant Children in The Netherlands. International Journal of Psychology, 34(3), 149-162.

Verkuyten, M. (2001). Global self-esteem, ethnic self-esteem, and family integrity: Turkish and Dutch early adolescents in The Netherlands. International Journal of Behavioural Development, 25(4), 357-366. 